\title{
TAMBANG INKONVENSIONAL: PERAN MASYARAKAT DAN DAYA TARIK EKONOMI BAGI PENAMBANG
}

\author{
The Unconventional Mine: Role of Community and Economic \\ Attraction for Miners
}

\author{
SULISTA \\ Bappeda Provinsi Kepulauan Bangka Belitung \\ Jalan Pulau Belitung No. 2, Komplek Perkantoran Provinsi Kepulauan Bangka Belitung \\ Telp. (0717) 439333, 439335, 439336 \\ e-mail: sulista.25051986@gmail.com
}

\begin{abstract}
ABSTRAK
Masih tingginya aktivitas pertambangan timah rakyat di Provinsi Kepulauan Bangka Belitung membuktikan bahwa timah merupakan komoditas penting dalam membentuk ekonomi masyarakat pedesaan. Tujuan penelitian ini adalah diperolehnya informasi tentang bagaimana masyarakat memainkan perannya dalam aktivitas pertambangan rakyat dan kontribusi ekonomi yang diperoleh sehingga aktivitas ini menjadi tumpuan ekonomi. Metodologi penelitian dilakukan melalui wawancara terhadap aparatur pemerintahan desa dan pelaku pertambangan untuk memetakan kelompok masyarakat yang beraktivitas di sektor ini, selanjutnya dilakukan wawancara mendalam terhadap kelompok masyarakat tersebut guna mendapatkan informasi tentang daya tarik ekonomi dari tambang rakyat ini. Dari hasil penelitian, diketahui bahwa aktivitas masyarakat dalam proses pertambangan rakyat terdiri dari pelimbang timah, pekerja tambang inkonvensional, penambang dengan menggunakan pompa air, pemilik tambang inkonvensional, pekerja lobi timah, dan pembeli timah. Aktivitas tersebut sangat berpengaruh terhadap kondisi ekonomi masyarakat penambang yang dikelompokkan ke dalam pelaku pertambangan berpenghasilan rendah yaitu pelimbang, pekerja tambang inkonvensional (TI), pekerja robin, berpenghasilan sedang yaitu pekerja lobi timah, berpenghasilan tinggi yaitu pemilik TI serta berpenghasilan sangat tinggi yaitu pembeli timah. Hasil penelitian ini diharapkan dapat dijadikan masukan bagi pemerintah daerah dalam merumuskan strategi pembangunan di Provinsi Kepulauan Bangka Belitung.
\end{abstract}

Kata kunci: ekonomi pedesaan, peran masyarakat, tambang inkonvensional, timah.

\begin{abstract}
The high activity of tin mining in Bangka Belitung Islands Province proves that tin is an important commodity in shaping the economy of rural society. The purpose of this research is to obtain information about how society plays its role in people's mining activity and economic contribution, therefore this activity becomes economic support. The research methodology was conducted through interviewing with village government apparatus and mining stakeholders to map the community groups in this sector and then conducted in-depth interviewing with the community groups to obtain information on the economic attraction from the people's mine. From the result of the research, it is known that community activities in the community mining process consist of tin artisanal miners/tin small scale miners, unconventional mine worker, miner using water pump, unconventional mine owners, tin lobby workers, and tin buyers. This activity greatly affect the economic condition of miners who are grouped into low-income mining stakeholder such as artisanal miners/small scale miners, IT workers, Robin workers, middle income is tin lobby workers, high income is IT owners, and very high income is tin buyers. The results of this study are expected to be an input for local government in formulating development strategies in Bangka Belitung Province.
\end{abstract}

Keywords: the economy of rural society, community role, unconventional mine, tin. 


\section{PENDAHULUAN}

Telah diketahui khalayak umum bahwa sektor pertambangan timah termasuk keterdapatan tambang inkonvensional (TI) merupakan penopang perekonomian terpenting di Provinsi Kepulauan Bangka Belitung. TI merupakan klasifikasi tambang yang dipakai oleh PT. Timah Tbk untuk suatu kegiatan penambangan dengan kemampuan pemindahan material tambang di bawah 30 $\mathrm{m}^{3} /$ jam. Pengertian ini kemudian mengalami pergeseran menjadi kegiatan penambangan pasir timah yang dilakukan oleh masyarakat yang secara umum tidak memiliki izin dari pemerintah. Konsekuensinya penambangan yang dilakukan tidak melaksanakan kewajiban reklamasi dan membayar royalti walaupun peralatan yang dipakai sudah menyamai kemampuan sebuah tambang besar (Zulkarnain dkk., 2005).

Menurut Erman (2010), komoditas timah dari masa VOC hingga kini adalah sumber pendapatan terpenting di Pulau Bangka. Pendapat ini cukup beralasan mengingat sejak berdirinya provinsi ini, sektor pertambangan dan penggalian dengan industri pengolahan memberikan kontribusi sebesar 30 hingga 40 persen terhadap struktur perekonomian daerah, meskipun menunjukkan penurunan dalam beberapa tahun terakhir. Penurunan rata-rata 5,64 persen pertahun dari 39,69 persen pada 2012 menjadi 31,45 persen pada 2016, akan tetapi masih merupakan sektor tertinggi pendukung PDRB (Badan Pusat Statistik, 2016a). Pentingnya peranan timah ini pun terlihat ketika terjadi penurunan harga komoditas sepanjang tahun 2015 pada bursa Indonesia Commodity \& Derivatives Exchange (ICDX) yang jatuh hingga ke angka 14.000 \$/MT mengakibatkan Pemerintah Daerah berupaya mendorong smelter untuk membatasi jumlah ekspor timah. Beberapa bulan setelah upaya pembatasan ekspor timah tersebut, diterbitkan Peraturan Menteri Perdagangan nomor 33 tahun 2015 tentang Ketentuan Ekspor Timah dengan harapan akan menaikkan harga komoditas ini. Sebelumnya moratorium ekspor timah pernah dilakukan pada akhir tahun 2011 oleh Asosiasi Industri Timah Indonesia (AITI) dengan tujuan untuk menstabilkan harga timah di pasar dunia sebagai reaksi balik terhadap menurunnya harga timah pada saat itu. Turunnya harga komoditas ini menjadi salah satu penyebab terjadinya perlambatan ekonomi Provinsi Kepulauan Bangka Belitung dalam rentang 2011 hingga 2015 dari 6,90 menjadi 4,08 persen.

Pada 2016, Badan Pusat Statistik mencatat ada 73.939 tenaga kerja usaha pertambangan dan penggalian dan 37.369 tenaga kerja usaha industri pengolahan timah (Badan Pusat Statistik, 2016b). Kedua sektor ini didominasi oleh tenaga kerja usaha mikro yang merupakan kegiatan pertambangan rakyat. International Institute for Environment and Development (2002) melaporkan kegiatan penambangan tradisional dan skala kecil menjadi sumber penghidupan penting bagi wanita dan anakanak yang terlibat dalam kegiatan penambangan, terutama ketika berada pada situasi kemiskinan. Sektor ini pun menimbulkan efek domino terhadap ekonomi lokal antara lain peningkatan daya beli yang signifikan dan munculnya arus permintaan dan penawaran terhadap barang dan jasa untuk memenuhi kebutuhan daerah setempat (makanan, peralatan, perumahan, dan infrastruktur).

Kemunculan TI di Pulau Bangka Belitung menurut Subiman dan Resosudarmo (2010) didasari oleh 3 faktor yaitu: (1) keputusan PT. Timah pada awal tahun 1990-an untuk mensubkontrakkan sebagian proyek penambangan timah daratnya kepada pengusaha lokal akibat krisis timah dunia pada tahun 1985 dan pada pola subkontrak inilah pertama kali istilah TI diperkenalkan, (2) kejatuhan harga komoditas lada (Piper ningrum L) sebagai komoditas utama pertanian Bangka pada penghujung tahun 1990-an menyebabkan penurunan pendapatan masyarakat lokal, (3) pemisahan Bangka Belitung dari Provinsi Sumatera Selatan sebagai akibat diterapkannya kebijakan otonomi daerah dan terjadinya krisis ekonomi pada 1997-1998 yang menyebabkan lemahnya sistem pemerintahan di Pulau Bangka. Ketiga hal ini yang mendorong masyarakat melakukan penambangan secara terbuka. Di samping karena kebutuhan ekonomi juga anggapan masyarakat bahwa ada rasa ketidakadilan terhadap rakyat kecil dalam menikmati kekayaan alam yang dimiliki di tanah negeri mereka sendiri.

Menurut Zulkarnain (2010), ada dua aspek yang menyebabkan tetap berlangsungnya kegiatan masyarakat menambang secara terus 
menerus dan cenderung turun temurun. Pertama, sifat kegiatan tersebut dapat menghasilkan uang secara cepat (instant money) dan kadangkala dalam jumlah yang cukup signifikan sehingga menimbulkan harapan bagi yang ingin mengubah nasibnya dengan cepat. Kedua, kegiatan tersebut tidak memerlukan pengetahuan dan keahlian yang tinggi, tetapi lebih berdasarkan pengalaman dengan bermodalkan tenaga dan keberanian. Kedua hal tersebut yang menyebabkan kegiatan menambang menjadi salah satu pilihan yang sangat menarik untuk dijadikan mata pencaharian, terutama bagi mereka yang berpendidikan terbatas dan memiliki kondisi fisik yang cukup kuat. Kegiatan menambang merupakan kehidupan yang mereka nikmati dan jalani untuk memenuhi kebutuhan ekonomi sepanjang kehidupannya.

Kelimpahan sumber daya alam memiliki hubungan positif terhadap pendapatan suatu negara didukung oleh kemampuan modal insan dalam membantu pertumbuhan ekonomi (Kunchu dan Sarmidini, 2015). Di Indonesia sektor pertambangan berpengaruh positif yang signifikan terhadap pertumbuhan PDRB di provinsi-provinsi di Indonesia (Hermawan, 2014). Namun beberapa daerah di tingkat kabupaten/kota, sektor ini tidak memberikan dampak dikarenakan dana bagi hasil sumber daya alam tidak dimanfaatkan pada sektor yang memberikan multiplier effect seperti pendidikan dan kesehatan (Martawardaya, Basuki, dan Hanafi, 2014). Bahkan, sejumlah provinsi di Indonesia teridentifikasi mengalami kerusakan sumber daya alam (Haryanto, 2018). Studi-studi ini menunjukan bahwa pertentangan antara dampak positif ekonomi dan dampak negatif masih menjadi permasalahan serius di daerahdaerah yang mengandalkan sektor pertambangan sebagai komoditas unggulan pembentuk struktur perekonomian daerah.

Sejauh ini kajian penambangan timah rakyat didominasi oleh dampak negatifnya yang dirasa lebih besar baik terkait isu lingkungan, regulasi, konflik pertimahan dan dampak sosial ekonominya yang cenderung negatif. Namun masih sedikit kajian tentang kegiatan pertambangan timah rakyat yang menunjukkan sebagai komponen inti sumber pendapatan utama bagi ekonomi masyarakat pedesaan.
Adiatma, Bambang dan Purnaweni (2013), serta Marfirani dan Adiatma (2012) menyebutkan bahwa aktivitas TI Apung di Desa Batu Belubang memberikan peningkatan kapasitas ekonomi dengan pendapatan tiga juta rupiah per bulan bagi buruh TI dan bagi pemilik tambang dalam 1 minggu dapat menghasilkan belasan juta rupiah serta memicu timbulnya dampak ganda walaupun dinilai belum efektif menjamin keberlanjutan lingkungan. Sedangkan Harliyana dan Radjiman (2008) menyebutkan bahwa pengaruh penambangan timah rakyat terhadap kondisi sosial ekonomi masyarakat bagi sebagian penambang hanya bisa mencukupi kebutuhan hidup sehari-hari saja. Peningkatan kesejahteraan hanya terjadi pada para pemilik tambang skala kecil, tetapi itupun belum sebanding dengan resiko yang dihadapi, baik resiko secara ekonomi maupun keselamatan kerja.

Kegiatan penambangan rakyat yang dilakukan di berbagai daerah lainnya seperti penambangan emas rakyat di Gunung Pongkor, juga merupakan sumber pendapatan penting. Bagi penduduk lokal, baik yang terlibat secara langsung maupun tidak, turut merasakan dampak ekonomi yang cukup besar dari kegiatan penambangan rakyat ini (Pudjiastuti, 2005). Pudjiastuti (2010) menyebutkan kegiatan penambangan emas masyarakat Mombana merupakan kegiatan yang menghasilkan dampak multiplier yaitu terbentuknya pasar yang menjual beras hingga linggis, bahkan tersedia praktek lokalisasi terselubung, terjadi perputaran uang yang diperkirakan bisa mencapai miliran rupiah per hari. Dampak lainnya adalah berdirinya warung-warung yang merupakan warung tumbuh, yaitu ramai menjamur ketika mulai ada penambang yang menjual berbagai macam kebutuhan penambang. Warungwarung ini menjual berbagai macam kebutuhan penambang mulai dari makanan dan bahan makanan, kelengkapan tambang hingga kelengkapan untuk bermukim, seperti tikar, tenda, tali dan lainnya. Begitu pula kegiatan penambangan emas liar di Desa Kebun Lado Kecamatan Singingi Kabupaten Kuantan Singingi, kegiatan penambangan emas liar memberikan besaran pendapatan bagi masyarakat sehingga mereka terus bekerja sebagai penambang emas liar walaupun dari segi hukum merupakan pekerjaan ilegal (Eriyati dan lyan, 2011). 
Dari penelitian-penelitian tersebut di atas, masih belum terungkap sejauh mana kegiatan penambangan memengaruhi kehidupan ekonomi para penambang yang pada akhirnya melibatkan masyarakat dalam berbagai tingkatan. Dalam tulisan ini, telah dikaji lebih dalam bagaimana masyarakat Bangka Belitung beraktivitas di sektor pertambangan timah, kemudian melakukan analisis kontribusi kegiatan ini secara ekonomi bagi keluarga. Diharapkan dapat memberikan gambaran seimbang tentang pertambangan timah rakyat dan menjadi bahan pertimbangan bagi pemerintah dalam mengambil kebijakan yang dapat dilihat dari berbagai sudut pandang.

\section{METODE}

Metode yang digunakan adalah deskriptif kualitatif yaitu melakukan wawancara mendalam dengan aparatur pemerintahan desa dan pelaku pertambangan untuk mengetahui bagaimana masyarakat beraktivitas dalam sektor pertambangan ini. Wawancara yang mendalam dilanjutkan kepada masyarakat yang terlibat untuk mengetahui dampak ekonomi yang diperoleh. Studi literatur berupa artikel dan kajian yang berkaitan sebagai bahan perbandingan, dan data sekunder berupa data publikasi BPS antara lain Provinsi Kepulauan Bangka Belitung Dalam Angka, Sensus Ekonomi Tahun 2016 (Badan Pusat Statistik, 2016b), dan website ICDX (ICDX, 2016) untuk mengetahui harga timah global.

Lokasi penelitian ditentukan berdasarkan hasil pengamatan langsung, yaitu di Desa Penyak yang sebagian besar warganya memiliki mata pencaharian yang signifikan di sektor pertambangan (TI Rajuk) dan akses ke lokasi penelitian yang mudah dijangkau. Waktu penelitian dilakukan dari Agustus 2015 s.d. Februari 2016. Pemilihan responden dipilih secara purposive sampling. Responden dipilih dan disesuaikan berdasarkan keterwakilan dari jenis keterlibatannya yaitu penambang timah yang secara langsung menambang di dalam bumi, pemilik tambang, warga yang memanfaatkan ampas timah, dan pembeli serta lainnya yang menjadi temuan di lapangan. Selain itu banyaknya jumlah warga yang terlibat menjadi pertimbangan dalam penelitian ini. Wawancara dilakukan berdasarkan pedoman wawancara yang telah dirumuskan menurut aspek dan variabel yang ingin diketahui. Tahapan verifikasi dilakukan untuk setiap kegiatan ekonomi yang saling berkaitan. Dalam prosesnya digunakan alat bantu rekaman berupa tape recorder.

Untuk memetakan aktivitas masyarakat dalam usaha pertambangan mengacu kepada kutipan dari Buxton (2013) yang menyebutkan bahwa keragaman penambangan skala kecil dapat diamati dari sisi penambangan yang paling dasar dengan hanya sekedar mengambil dan menggunakan sekop hingga menggunakan mesin sederhana, maupun dari sisi pekerjaannya sebagai diggers, miner or gang leader. Diggers yaitu buruh upahan yang menggali, mencuci, mengangkut, menyortir limbah dan mengangkut atau memberikan keamanan, termasuk di dalam kelompok ini adalah wanita, orang tua dan anak-anak. Miner atau gang leader yaitu pemilik peralatan atau pemilik pit yang menanggung semua biaya pekerjaan.

Zulkarnain $d k k$. (2005) memetakan beberapa pihak yang berperan dalam kegiatan TI yaitu (1) pemodal adalah orang atau sekelompok orang yang menyediakan modal untuk pekerjaan $\mathrm{TI}$, (2) pemilik $\mathrm{TI}$ yaitu orang memiliki unit TI dan melakukan kegiatan $\mathrm{TI}$ sendiri maupun mempekerjakan orang lain untuk menjalankan kegiatan TI. (3) pekerja TI adalah buruh-buruh yang bekerja pada unit $\mathrm{TI}$ yang biasanya berjumlah 3-4 orang, (4) pengumpul/kolektor yaitu orang yang membeli timah dari para TI dan mengumpulkannya sebelum dijual kepada perusahaan.

Indra (2013) menyebutkan istilah dalam pertambangan untuk masyarakat yang terlibat dalam pertambangan terdiri dari penambang (orang yang bekerja di TI-TI), pelimbang (masyarakat yang bisa terdiri dari bapakbapak, ibu-ibu, anak-anak, atau kombinasi semuanya yang mengayak atau mengais timah sisa pembuangan pencucian $\mathrm{TI}$ orang lain) dan kolektor (individu atau beberapa orang yang melakukan aktivitas membeli timah dari para pelimbang $\mathrm{TI}$ atau penyelewengan timah). Erman (2014), Marfirani dan Adiatma (2012) menyebutkan adanya multiplier effect pertambangan timah yaitu terbentuknya pasar malam dan jasa pertukangan. 
Sementara itu, dampak ekonomi diukur berdasarkan besaran pendapatan yang diperoleh oleh masyarakat yang terlibat dalam aktivitas pertambangan baik langsung maupun tidak. Menurut Sukirno (2006) pendapatan adalah jumlah penghasilan yang diterima oleh penduduk atas prestasi kerjanya selama satu periode tertentu, baik harian, mingguan, bulanan maupun tahunan. Lumintang (2013) dalam penelitiannya mengungkapkan bahwa besarnya pendapatan yang diterima oleh penduduk sangat dipengaruhi oleh biaya produksi dan penerimaan. Pendapatan yang diperoleh oleh setiap individu pun berbeda yang disebabkan oleh faktor usia, karekteristik bawaan sejak lahir, keberanian mengambil resiko, bobot latihan, kekayaan dan warisan, keseimbangan pasar dan diskriminasi (Eriyati dan lyan, 2011).

Berdasarkan studi pustaka tersebut dikombinasikan dengan pengamatan lapangan, untuk mempermudah penelitian yang dilakukan, dirumuskan aspek, variabel, indikator dan sumber data yang menjadi panduan wawancara seperti diuraikan pada Tabel 1.

Pengolahan data dilakukan melalui empat tahapan. Tahapan pertama yaitu menyusun transkripsi hasil wawancara semua narasumber. Kedua, pemberian kode aspek, variabel dan indikator. Ketiga, ekstraksi terhadap data dan informasi berdasarkan koding yang telah disusun. Keempat, tahapan kategorisasi yaitu pengelompokan hasil wawancara berdasarkan hasil ekstraksi data untuk melihat kecenderungan dari data yang diperoleh. Data diolah menggunakan model explanatory approach yaitu model analisis dengan memberikan penekanan pada eksplorasi berbagai data lapangan dan realitas yang ditemui sekaligus memberikan interpretasi terhadap objek penelitian untuk menjawab persoalan atau rumusan masalah yang telah dituangkan dalam pertanyaan penelitian.

\section{HASIL DAN PEMBAHASAN}

\section{Peran Masyarakat dalam Aktivitas Pertambangan Rakyat}

Peralihan mata pencaharian masyarakat Desa Penyak dari sektor pertanian dan perikanan menuju sektor pertambangan terjadi pada 2011. Peralihan tersebut diawali oleh salah seorang warga yang melakukan aktivitas penambangan dengan membuka unit TI sistem Rajuk di salah satu lokasi cadangan timah yang masuk Izin Usaha Pertambangan (IUP) PT. Kobatin. Mereka mendapat informasi kandungan timah di daerah tersebut melalui tenaga kontrak eksplorasi yang pernah dipekerjakan oleh perusahaan tersebut.

Tabel 1. Aspek, variabel, indikator dan sumber data penelitian

\begin{tabular}{|c|c|c|c|c|}
\hline No. & Aspek & Variabel & Indikator yang diamati & Sumber Data \\
\hline 1 & $\begin{array}{l}\text { Sumber penghidupan } \\
\text { masyarakat }\end{array}$ & $\begin{array}{l}\text { Sejarah peralihan mata } \\
\text { pencaharian }\end{array}$ & $\begin{array}{l}\text { - Jenis pekerjaan } \\
\text { - Tahun peralihan } \\
\text { - Gambaran } \\
\text { pendapatan } \\
\text { masyarakat } \\
\end{array}$ & $\begin{array}{l}\text { Primer } \\
\text { (aparatur pemerintahan } \\
\text { desa dan tokoh } \\
\text { masyarakat) }\end{array}$ \\
\hline 2 & $\begin{array}{l}\text { Kegiatan ekonomi } \\
\text { kelompok masyarakat } \\
\text { yang terlibat langsung } \\
\text { dalam kegiatan } \\
\text { penambangan }\end{array}$ & $\begin{array}{l}\text { Kelompok diidentifikasi } \\
\text { terdiri dari: } \\
\text { - } \text { Digger } \\
\text { - } \text { Miner/Gang Leader } \\
\text { - } \text { Kolektor } \\
\text { - Lainnya }\end{array}$ & $\begin{array}{l}\text { - Kegiatan ekonomi } \\
\text { yang dilakukan dalam } \\
\text { pertambangan rakyat } \\
\text { - Tahun peralihan } \\
\text { - Pendapatan }\end{array}$ & $\begin{array}{l}\text { Primer } \\
\text { (warga lokal yang } \\
\text { sumber pendapatan } \\
\text { utama diperoleh dari } \\
\text { kegiatan pertambangan } \\
\text { rakyat setempat) }\end{array}$ \\
\hline 3 & $\begin{array}{l}\text { Kegiatan ekonomi } \\
\text { kelompok masyarakat } \\
\text { yang ikut terdampak } \\
\text { akibat adanya } \\
\text { masyarakat yang } \\
\text { menambang } \\
\end{array}$ & $\begin{array}{l}\text { Kelompok diidentifikasi } \\
\text { terdiri dari: } \\
\text { - } \quad \text { Pedagang } \\
\text { - } \quad \text { Jasa Pertukangan } \\
\text { - } \\
\text { Lainnya }\end{array}$ & $\begin{array}{ll}\text { - } & \text { Kegiatan ekonomi } \\
& \text { yang sedang } \\
\text { berlangsung } \\
\text { - } & \text { Pendapatan }\end{array}$ & $\begin{array}{l}\text { Primer } \\
\text { (warga lokal yang } \\
\text { berjualan, pedagang } \\
\text { pasar malam dan } \\
\text { lainnya yang merasakan } \\
\text { dampak ekonomi) } \\
\end{array}$ \\
\hline
\end{tabular}


Kegiatan tersebut ternyata secara ekonomi menghasilkan dan terdengar oleh warga lainnya sehingga mengundang banyak orang yang berprofesi sebagai nelayan, petani, buruh (tukang kayu/anak buah nelayan) dan lainnya ikut membuka unit TI di lokasi tersebut, tepatnya di hulu sungai Kurau. Pada saat itu \pm 80 persen warga desa beralih pekerjaan ke sektor pertambangan. Aktivitas penambangan mencapai puncaknya pada 2013 dan 2014. Pada masa itu, satu orang pemilik TI memiliki minimal 2 atau 3 unit TI dan rata-rata satu unit TI bisa menghasilkan 100-150 kg pasir timah dalam satu hari atau 500-600 kg pasir timah dalam satu minggu. Hingga saat ini, ekonomi desa Penyak masih sangat bergantung pada sektor ini.

Tahapan pekerjaan TI terdiri dari proses pengambilan pasir timah yang bercampur air (slurry) menggunakan pompa tanah (gravel pump). Air berasal dari pompa air (water pump), melalui pipa mengalirkan air yang bersumber dari kolong atau lubang galian yang telah terisi air menuju sump yaitu lubang galian berbentuk sumuran yang terdapat pasir timah tempat pompa tanah diletakkan. Pompa tanah yang terhubung dengan pipa akan mengalirkan slurry. Ampas akan langsung keluar melalui ujung pipa ke tempat pembuangan, sedangkan pasir timah akan mengendap di sepanjang dasar pipa. Pada akhir penambangan, ujung pipa dipindahkan ke unit pencucian. Pompa tanah akan menghisap air dengan tekanan lebih kuat sehingga pasir timah keluar melalui ujung pipa menuju unit pencucian yang disebut oleh masyarakat setempat dengan istilah sakan.

Dalam dunia pertambangan, sakan lebih dikenal dengan istilah palong/khan/sluice box yang terbuat dari papan/kayu dengan dimensi ukuran lebar dasar 3-4 meter, panjang 32 meter, dan tinggi 1 meter, serta kemiringan 2-2,5 persen (Sujitno, 2007). Hanya saja sakan didesain dengan ukuran yang lebih kecil disesuaikan dengan kapasitas produksi timah dengan dimensi ukuran lebar 2 meter, panjang 4 meter, dan tinggi 1 meter, serta kemiringan 15 persen. Pada unit sakan, pasir timah disemprot menggunakan monitor dengan tekanan tertentu. Dengan bantuan air dan gravitasi, butiran timah akan mengendap sedangkan air dan lumpur akan mengalir ke luar. Kadar timah (Sn) yang dihasilkan dari proses pencucian ditimbang menggunakan timbangan sehingga diketahui kadar rata-rata 1,2 kg. Ampas yang dihasilkan mengandung pasir timah berkadar rendah tetapi masih bisa dimanfaatkan.

Tidak dapat dipungkiri, hadirnya TI di suatu komunitas telah memberikan kesempatan kerja bagi banyak orang. Tidak hanya pemilik TI dan pekerjanya tetapi ada kelompok masyarakat yang ikut menambang dengan memanfaatkan ampas yang dihasilkan oleh TI tersebut yaitu pelimbang timah dan pekerja robin. Satu unit TI terdiri dari 3-4 orang pekerja, ditambah lagi dengan pelimbang timah dan pekerja robin hingga terdapat puluhan orang pada suatu lokasi. Terdapat pula reman masak yaitu istilah yang digunakan bagi masyarakat setempat yang menyediakan makanan bagi pekerja $\mathrm{TI}$, dan pekerja yang melobi timah. Bermunculan warung kecil yang menjual makanan ringan dan toko yang menjual spare part $\mathrm{TI}$, serta terbentuknya pasar malam. Kegiatan ekonomi akibat adanya TI dapat diamati pada Gambar 1 .

Aktivitas masyarakat dalam pertambangan rakyat terdiri dari 4 kelompok yaitu (1) kelompok masyarakat yang menambang timah menggunakan alat sederhana berupa sekop/cangkul maupun menggunakan mesin, (2) kelompok masyarakat yang terlibat dalam proses pencucian lanjutan dan pengeringan timah, (3) pemilik tambang yang memiliki unit penambangan dan bertanggung jawab terhadap operasional tambang, dan (4) kelompok masyarakat yang terlibat dalam pemasarannya.

Kelompok penambang terdiri dari pekerja/buruh $\mathrm{TI}$, pelimbang timah dan pekerja robin. Pekerja TI bekerja pada pemilik TI dan menambang dengan unit TI. Pelimbang timah menambang menggunakan pengeruk yang terbuat dari pipa untuk mengambil pasir ampas dan dimasukkan ke dalam piring untuk kemudian ditampung ke dalam kampil/karung. Pasir timah tersebut dicuci menggunakan karpet yang posisinya diatur dengan kemiringan tertentu. Timah kemudian ditimbang dan diketahui kadar rata-rata 1-1,1 kg. Adakalanya pelimbang timah ikut membantu kegiatan TI yang disebut dengan reman $\mathrm{TI}$. Jasa reman $\mathrm{TI}$ dibayar dengan beberapa kilogram pasir timah disesuaikan dengan banyak sedikitnya perolehan pasir timah pada hari itu juga. 


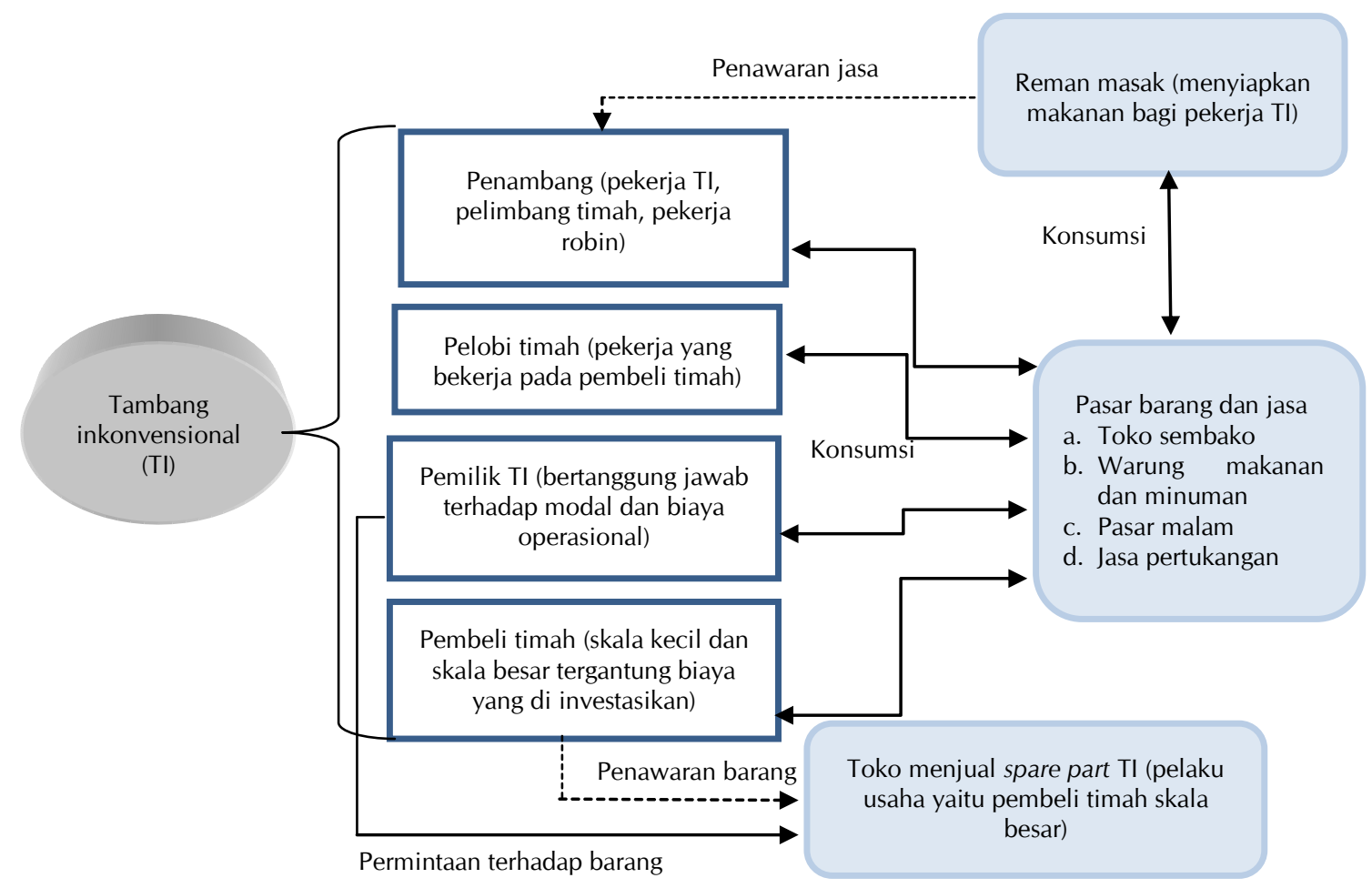

Sumber: Pengolahan data lapangan

Gambar 1. Kegiatan ekonomi komunitas pedesaan usaha pertambangan timah rakyat

Sedangkan pekerja robin merupakan istilah setempat untuk kelompok penambang yang menambang menggunakan satu unit pompa air yang dihubungkan dengan pipa sebagai unit penambangan. Pada umumnya beroperasi di ujung unit pencucian $\mathrm{TI}$ yaitu tempat pembuangan ampas. Operator akan menyemprot pasir ampas menggunakan pompa air. Pasir timah akan terkumpul pada sump dan dimasukkan ke dalam karung untuk dibawa ke unit pencucian. Proses pencucian menggunakan karpet seperti halnya pelimbang timah. Kadar timah yang diperoleh tidak jauh berbeda dengan kadar timah hasil melimbang.

Kelompok masyarakat yang berperan dalam proses lanjutan bertugas melobi timah atau melakukan tahapan pencucian kembali. Setelah itu timah dikeringkan menggunakan tungku pemanas untuk mengurangi kadar air. Timah kering ditimbang menggunakan neraca ohaus sehingga diperoleh kadar timah yang dapat diterima oleh pasar.

Sementara itu masyarakat yang terlibat dalam pemasaran atau jual beli pasir timah terdiri dari pembeli timah skala kecil dan pembeli timah skala besar sesuai dengan besarnya modal yang dikeluarkan. Para pembeli timah membeli timah secara langsung dari para penambang, mendatangi lokasi penambangan ataupun para penambang yang mendatangi para pembeli.

Aktivitas yang dilakukan oleh pelaku pertambangan timah dipengaruhi oleh modal finansial dan kondisi fisik, usia, jenis kelamin, serta tingkat pendidikan. Modal besar diperlukan oleh pembeli timah untuk membeli timah dari penambang. Begitu pula pemilik TI memerlukan investasi besar untuk dapat membeli peralatan dan perlengkapan penambangan serta menanggung biaya operasional. Sementara itu, pekerja robin memerlukan cukup uang untuk modal awal dan biaya operasional walaupun tidak sebesar pemilik TI. Kondisi fisik yang kuat dan tenaga yang lebih besar diperlukan pada tingkatan pekerja TI dan pelobi timah, sedangkan pelimbang timah tidak memerlukan fisik yang kuat dan modal yang dikeluarkan relatif kecil.

Melimbang timah merupakan pekerjaan yang relatif santai dan ramai dilakukan ketika 
tahapan pencucian TI. Kegiatan ini dilakukan selama 4-5 hari kerja dari jam 10 pagi hingga jam 5 sore sehingga melimbang dapat dilakukan oleh anak usia sekolah dasar dan para wanita. Sama halnya dengan melimbang, para pekerja robin, tidak memerlukan fisik yang kuat dengan aktivitas yang cenderung santai dan juga bekerja ketika para pekerja $\mathrm{TI}$ melakukan tahapan pencucian. Namun pekerja kategori ini memerlukan modal yang cukup besar untuk membeli satu unit alat untuk menambang, serta biaya perbaikan dan pergantian spare part yang rusak.

Tenaga yang besar dan kondisi fisik yang prima diperlukan oleh pekerja TI untuk menjalankan kegiatan penambangan. Pada TI rajuk, para pekerja menggunakan pipa besi untuk merajuk hingga kedalaman lebih kurang 20 meter. Sedangkan pada TI darat, pekerja menyemprot lapisan dinding pasir untuk melepaskan bijih timah dari gumpalan material. Setelah itu pekerja TI juga melakukan proses pencucian menggunakan sakan. Sementara pemilik TI hanya bertanggungjawab atas permodalan dan kelancaran operasional TI.

Pembeli timah memerlukan modal besar untuk membeli timah dari penambang. Besar kecilnya modal yang dikeluarkan tergantung kepada banyak sedikitnya timah yang dibeli. Dalam rutinitas pekerjaannya, kegiatan melobi dilakukan oleh pekerja lobi dengan fisik yang prima karena dikejar oleh target dan waktu. Timah yang dibeli dalam satu minggu dikumpulkan terlebih dahulu, kemudian dilobi hingga selesai.

Selain para penambang, kehadiran TI memicu bermunculannya para pedagang yang berjualan di pasar malam yang terdiri dari puluhan pedagang (penjual kaset, penjual buah, pedagang baju, pedagang sembako, pedagang sayur-sayuran), kuli bangunan, warung-warung kecil yang menjual makanan dan minuman ringan, toko sembako, dan reman masak.

\section{Daya Tarik Ekonomi Tambang Inkonvensional}

Pendapatan yang diperoleh dari kegiatan pertambangan rakyat merupakan komponen inti sumber utama pendapatan masyarakat yang terlibat tersebut. Nurtjahya, Agustina dan Putri (2008) menyebutkan bahwa pendapatan dari penambangan timah memberi kontribusi yang signifikan terhadap total pendapatan keluarga per bulan, yaitu sebesar 89 hingga 95 persen. Kondisi ini memberikan dampak positif bagi peningkatan penghasilan walaupun kerugian yang diderita oleh penambang timah memang terbukti ada, tergantung dari besar kecilnya kerugian akibat investasi yang dibelanjakan, luas lahan, dan lama operasional yang merugi.

Subiman dan Resosudarmo (2010) menyebutkan bahwa adanya pelaku $\mathrm{TI}$, memberikan manfaat keuangan yang besar. Tidak seperti bertani lada yang hasilnya baru didapat setidaknya setelah dua tahun memelihara tanaman ini, menambang timah dapat menghasilkan uang yang setara dengan jangka waktu 1 - 3 bulan saja. Hal ini dapat diamati dari ribuan rumah di tepi jalan yang dulunya terbuat dari kayu atau anyaman bambu kini telah direnovasi pemiliknya menjadi layaknya rumah-rumah di perkotaan dengan perangkat elektronik lengkap dan kendaraan pribadi.

Ada tiga hal yang memengaruhi besar kecilnya penghasilan para penambang yaitu harga timah, kadar timah, dan banyak sedikitnya timah yang diperoleh. Pada saat penelitian berlangsung harga timah hasil melimbang dan robin yaitu 40-50 ribu rupiah/kg kadar Sn 1,1, harga timah $\mathrm{TI} \pm 80$ ribu rupiah/kg rupiah kadar Sn 1,2 dan harga timah lobi 178-180 ribu rupiah/kg kadar Sn 69-72 persen. Tabel 2 menampilkan perbedaan pendapatan yang didapat oleh masyarakat yang terlibat dalam usaha pertambangan rakyat.

Dari Tabel 2 tersebut diketahui besarnya pendapatan pelaku pertambangan rakyat. Penghasilan terendah diperoleh oleh kelompok penambang yaitu pekerja TI, pelimbang timah dan pekerja robin. Khususnya pekerja TI memiliki penghasilan terendah dengan pendapatan 300-500 ribu rupiah/minggu dan memiliki resiko lebih besar dikarenakan sewaktu-waktu operasional bisa saja terhenti dan tidak sepadan dengan tenaga yang sudah dikeluarkan. Sementara itu, para pelimbang timah memperoleh pasir timah sebanyak 1-2 $\mathrm{kg} / \mathrm{hari}$ dengan 
penghasilan lebih kurang 500 ribu rupiah/minggu, pengeluaran relatif kecil, dan adakalanya seorang pelimbang ikut membantu pekerja TI yang disebut dengan reman TI. Para reman TI dibayar dengan 1-2 $\mathrm{kg}$ pasir timah sehingga mendapatkan penghasilan sebesar 800 ribu hingga 1 juta rupiah setiap minggunya.

Pekerja robin mendapatkan pasir timah \pm 15 $\mathrm{kg} /$ minggu dengan pendapatan rata-rata sebesar 900 ribu rupiah/minggu, lebih besar dibandingkan dengan pekerja TI dan pelimbang, tetapi biaya yang dikeluarkan juga lebih besar yaitu modal untuk membeli 1 unit robin dan kelengkapannya sebesar 3-4 juta rupiah, biaya operasional 100 ribu rupiah/hari, sehingga secara keseluruhan baik pekerja $\mathrm{TI}$, pelimbang timah maupun pekerja robin memiliki penghasilan yang hampir sama tiap minggunya.

Kegiatan para pelimbang dan pekerja robin sangat bergantung dari aktivitas TI karena memanfaatkan ampas yang dihasilkan oleh TI tersebut. Semakin banyak pasir timah yang dihasilkan maka semakin banyak pula ampas yang dibuang. Hanya saja para pelimbang maupun pekerja robin bisa berpindah-pindah dari satu lokasi TI ke TI lainnya dengan memperhatikan suatu kegiatan $\mathrm{TI}$ menghasilkan atau tidak. Berbeda halnya dengan pekerja $\mathrm{TI}$, seorang pekerja $\mathrm{TI}$ mendapatkan bagi hasil rata-rata sebesar 20 ribu rupiah untuk satu kilogram pasir timah dari kegiatan TI yang sedang berlangsung, bahkan sewaktu-waktu bisa saja tidak ada hasil yang didapat jika TI yang dioperasikan tidak mendapatkan pasir timah ataupun terjadi kerusakan alat yang mengakibatkan operasional terhenti.

Sementara itu, dengan tingkat penghasilan sedang adalah pekerja lobi yang bekerja pada pembeli timah mendapatkan rata-rata penghasilan 500-800 ribu rupiah/minggu. Pada umumnya pekerjaan ini dibayar 1000 rupiah/kilo yang dibagi dengan jumlah pekerja dan dilaksanakan 2-3 hari dalam seminggu. Para pekerja dibayar seminggu sekali. Selain itu pekerja lobi juga mendapatkan tambahan penghasilan dari penjualan ampas timah lobi dengan besaran rupiah tergantung dari bos, yaitu pembeli timah. Dari sisi pengeluaran, hampir tidak ada biaya yang dikeluarkan.

Tabel. 2. Pendapatan penduduk lokal yang terlibat langsung dalam kegiatan pertambangan rakyat

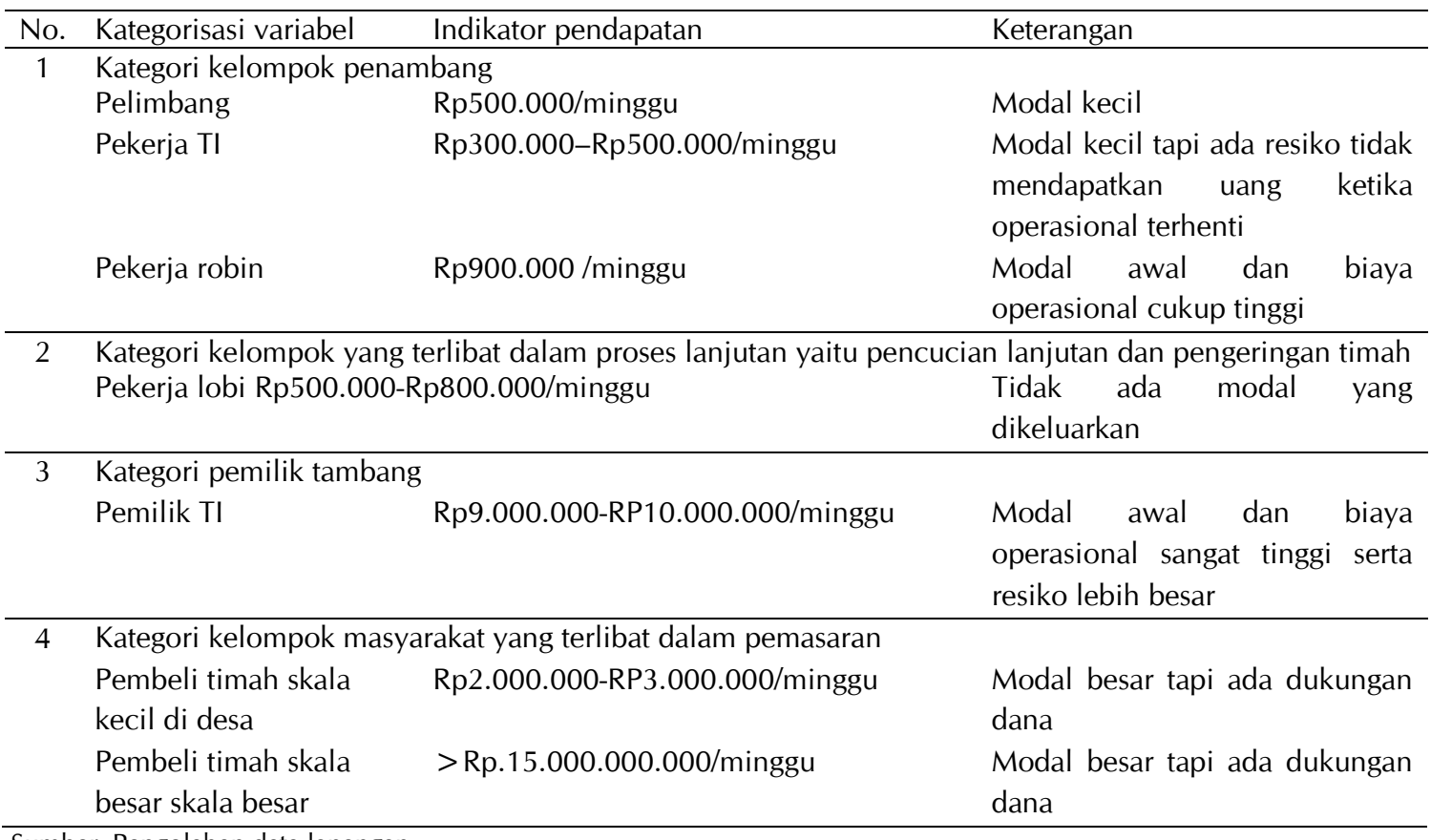

Sumber: Pengolahan data lapangan 
Pendapatan pemilik TI sangat bergantung kepada banyak sedikitnya pasir timah yang didapat dari operasional penambangan. Ratarata memiliki pendapatan kotor sebesar 9-10 juta rupiah/minggu. Sebagai pihak yang bertanggungjawab terhadap kelancaran operasional penambangan, pemilik TI memerlukan modal besar untuk biaya operasional sebesar 500-600 ribu rupiah/minggu, pergantian spare part dengan harga jutaan setiap minggunya. Modal awal untuk merangkai 1 unit TI rajuk yaitu TI yang beroperasi di wilayah daratan tetapi berlokasi di kolong ataupun rawa-rawa dengan kondisi baru yang mencapai 80-85 juta rupiah. Begitupula dengan TI darat yaitu TI yang berlokasi di darat, selain modal 1 unit penambangan TI yang mencapai puluhan juta, juga diperlukan modal yang cukup besar untuk menyewa excavator pengupas tanah penutup hingga kedalaman belasan meter, sehingga tidak jarang pemilik TI harus berhutang terlebih dahulu untuk modal sedangkan hasil yang diperoleh belumlah pasti.

Zulkarnain $d k k$. (2007) mengemukakan bahwa dalam mekanisme operasional TI, pihak yang paling menentukan adalah pemodal. Peranan pemodal dalam pendanaan TI menyebabkan adanya hubungan kerjasama yang saling menguntungkan. Pemilik TI memiliki modal yang kuat untuk membuka TI yang mencapai puluhan juta rupiah, sementara pemodal mendapatkan harapan besar dari sumber penerimaan timah yang akan diperoleh. Tidak jarang para pemodal ini kehilangan uang modal dalam jumlah besar karena kegiatan penambangan tersebut tidak berhasil, sementara itu mereka tidak dapat menuntut kerugian. Sangat sering baik pemilik TI maupun pemodal menghabiskan modal hingga ratusan juta rupiah tanpa hasil tetapi mereka tidak mengalami depresi seperti layaknya masyarakat umum (Zulkarnain, 2010).

Ketidakpastian pasir timah yang didapat dari TI selain berpengaruh terhadap besar kecilnya rupiah yang akan didapat oleh pemilik TI dan pekerjanya, berpengaruh pula pada pendapatan kelompok pelimbang dan pekerja robin. Akibat hasil yang spekulatif seringkali para pekerja TI cenderung terlibat hutang piutang dengan pemilik TI untuk menutupi kebutuhan rumah tangga. Tak jarang pula pekerja $\mathrm{TI}$ berpindah kerja dengan pemilik TI lainnya karena kegiatan $\mathrm{TI}$ tersebut tidak menghasilkan lagi. Begitupun dengan pemilik TI yang memerlukan modal awal yang besar seringkali terlibat hutang dengan pembeli pasir timah dengan konsekuensi menjual pasir timah yang didapat dengan pembeli pasir timah yang memberi hutang.

Kelompok yang memiliki keuntungan besar dengan kehadiran TI ini adalah kelompok pembeli pasir timah. Pembeli skala kecil memiliki pendapatan bersih sebesar 2-3 juta rupiah/minggu. Pembeli ini membeli pasir timah $\pm 500 \mathrm{~kg} / \mathrm{minggu}$ dari penambang yang selanjutnya melalui tahapan pelobian akan menghasilkan 300-350 kg timah kering, sementara pembeli timah skala besar membeli pasir timah hingga 5 ton/minggu dari penambang sehingga memiliki pendapatan bersih belasan hingga puluhan juta rupiah per minggunya. Teridentifikasi bahwa pembeli timah skala besar turut menjual spare part TI. Modal untuk membeli timah sangatlah besar hingga ratusan juta rupiah. Erman (2010) mengemukakan sejak 2005, beberapa investor berhasil dalam memproduksi pasir timah, membeli pasir timah dari penambang TI dan kadang-kadang juga menyuplai peralatan alat berat kepada penambang. Liberalisasi penambangan timah di era otonomi daerah telah membuka akses lebar kepada berbagai kelompok masyarakat, baik pemilik modal, supplier alat-alat penambangan, bahan bakar, penjual makanan, penyedia hiburan, dan para penambang dari dan luar Pulau Bangka untuk bersama-sama memperoleh keuntungan langsung ataupun tidak langsung dengan bisnis tersebut.

Dinamika ekonomi dari kegiatan TI memang bersifat spekulatif. Layaknya berjudi, di suatu waktu tampak menghasilkan tapi di lain waktu dapat meninggalkan hutang dalam jumlah besar. Faktanya adalah ketergantungan ekonomi yang tinggi menyebabkan kegiatan ini tidak serta merta dapat ditinggalkan. Sebagai sumber pendapatan utama penambang, uang yang diperoleh dimanfaatkan untuk memenuhi kebutuhan sehari-hari termasuk membiayai pendidikan anak-anak dan berobat.

Selain itu, akibat dari kehadiran TI ini secara tidak langsung merupakan sumber 
pendapatan bagi masyarakat yang terlibat dalam sektor perdagangan dan jasa antara lain nilai penjualan para pedagang di pasar malam sebesar 500 ribu hingga 3 juta rupiah setiap malamnya, warung-warung kecil dengan nilai penjualan 100 ribu hingga 200 ribu perharinya, lebih tingginya biaya yang harus dikeluarkan untuk jasa pertukangan yaitu tenaga pertukangan (warga asli desa) dengan upah 150 ribu/hari untuk kenek dan 200 ribu rupiah/hari untuk mandor. Hal ini dipicu ketika TI ini sangat menjanjikan, banyak masyarakat yang membangun unit rumah baru, serta reman masak mendapat imbalan jasa berupa 1-2 kg hasil timah.

\section{KESIMPULAN DAN SARAN}

\section{Kesimpulan}

Sektor pertambangan rakyat masih menjadi lapangan pekerjaan utama yang cukup signifikan bagi masyarakat Bangka Belitung. Mulai dari kelompok penambang hingga pembeli timah memanfaatkan pendapatan dari menambang untuk dapat memenuhi kebutuhan sehari-hari termasuk biaya pendidikan dan berobat. Kehadiran TI juga mendatangkan peluang ekonomi lainnya, terbukti adanya para reman masak, bermunculannya para pedagang yang berjualan di warung-warung dan pasar malam serta tingginya harga jasa pertukangan di desa ini. Keterlibatan perempuan di komunitas ini pun nampak sebagai pelimbang dan reman masak serta membuka usaha warung kecil yang turut membantu ekonomi keluarga.

Tampak pula ikatan permodalan dan hutang piutang antara pemilik tambang dengan pembeli timah dan hutang piutang antara pekerja dan pemilik tambang. Kondisi ini terjadi ketika biaya operasional lebih tinggi daripada pendapatan ataupun timah yang diperoleh semakin berkurang. Tidak menutup kemungkinan jika terjalin hutang pelimbang maupun pekerja robin dengan pemilik toko. Hal ini menggambarkan rentannya ekonomi dari kegiatan penambangan timah rakyat. Di sisi lain, warga yang menambang tidak memiliki sumber penghidupan lain yang mencukupi kebutuhan pada hari itu.

\section{Saran}

Pertambangan rakyat telah menjadi tumpuan ekonomi masyarakat yang terlibat di dalamnya. Hal ini pun tidak menjadi serta merta sumber penghidupan ini bisa langsung tergantikan oleh sektor lain mengingat dampak negatifnya terhadap keberlanjutan ekonomi dan ekologis. Pemerintah Daerah Kabupaten/Kota dan Pemerintah Provinsi di Kepulauan Bangka Belitung seyogyanya bersama-sama untuk dapat menyusun master plan jangka pendek antara lain dukungan permodalan usaha khususnya bagi istri penambang yang membuka warung dan master plan jangka panjang yaitu adanya percontohan penerapan standar operasional penambangan yang baik yang bisa diimplementasikan oleh penambang rakyat di Wilayah Pertambangan Rakyat dengan melibatkan engineer tambang yang ada di perusahaan korporasi. Selain itu, kegiatan peningkatan kapasitas keluarga penambang dan pendidikan kesadaran lingkungan sangat perlu untuk dipertimbangkan lebih lanjut. Dokumen-dokumen tersebut disusun terintegrasi lintas sektor dengan memperhatikan dampak positifnya terhadap ekonomi dan dampak negatifnya terhadap kerusakan lingkungan.

\section{UCAPAN TERIMA KASIH}

Dengan selesainya penelitian ini, penulis mengucapkan terima kasih kepada narasumber yang telah membantu memberikan data dan informasi yang terkait dengan masalah TI, antara lain aparatur pemerintahan desa, tokoh masyarakat dan pelaku pertambangan rakyat yang berada di lokasi penelitian. Di samping itu penulis juga mengucapkan terima kasih kepada Pemerintah Provinsi Kepulauan Bangka Belitung terutama Badan Perencanaan Pembangunan dan Penelitian Pengembangan Daerah Provinsi Kepulauan Bangka Belitung atas kontribusi pendanaan dan Badan Pusat Statistik Provinsi Kepulauan Bangka Belitung atas publikasi data sekunder mengenai sektor pertambangan. 


\section{DAFTAR PUSTAKA}

Adiatma, I., Bambang, A. N. and Purnaweni, H. (2013) 'Peralihan mata pencaharian sebagai bentuk adaptasi (Studi kasus: Desa Batu Belubang, Bangka)', Teknik, 34(2), p. 123. doi: 10.14710/teknik.v34i2.5637.

Badan Pusat Statistik (2016a) Data hasil pendaftaran usaha/perusahaan sensus ekonomi 2016 Provinsi Kepulauan Bangka Belitung. Bangka Belitung: Badan Pusat Statistik.

Badan Pusat Statistik (2016b) Provinsi Kepulauan Bangka Belitung dalam angka. Bangka Belitung: Badan Pusat Statistik.

Buxton, A. (2013) Responding to the challenge of artisanal and small-scale mining: How can knowledge networks help? London: IIED. Available at: http://pubs.iied.org/16532IIED/.

Eriyati and Iyan, R. Y. (2011) 'Dampak ekonomi dan lingkungan penambangan emas liar di Desa Kebun Lado Kecamatan Singingi Kabupaten Kuantan Singingi', Jurnal Ekonomi, 19(3), pp. 135-143. Available at: https://ejournal.unri.ac.id/index.php/JE/article/ view/819.

Erman, E. (2010) 'Aktor, akses dan politik lingkungan di pertambangan timah Bangka', Jurnal Masyarakat Indonesia, 36(2), pp. 71101. doi: 10.14203/jmi.v36i2.640.

Erman, E. (2014) 'Timah sebagai blessing atau resource curse?: Perempuan, komunitas, dan gerakan protes di pulau Belitung', Jurnal Masyarakat Budaya, 16(3), pp. 457-472.

Harliyana and Radjiman, G. (2008) Pengaruh penambangan timah rakyat terhadap perubahan fisik lingkungan dan sosial ekonomi masyarakat di Kecamatan Pemali Kabupaten Bangka. Universitas Gadjah Mada. Available at:

http://etd.repository.ugm.ac.id/index.php?mo $\mathrm{d}=$ penelitian_detail\&sub $=$ PenelitianDetail\&a $\mathrm{ct}=\mathrm{view} \& \mathrm{typ}=\mathrm{htm} \mid \& b u k u \_i d=38631$.

ICDX (2016) Historic Data, ww.icdx.co.id. Available at: http://www.icdx.co.id/marketdata-historical-indonesia-commodity-andderivatives-exchange/tinpb300/02/2016 (Accessed: 2 December 2016).

Indra, C. A. (2013) 'Dampak dari penambangan timah inkonvensional di Desa Lampur Kabupaten Bangka Tengah', Jurnal Society, 1(2). Available at: https://www.neliti.com/id/publications/13028 5/dampak-dari-penambangan-timah-

inkonvensional-di-desa-lampur-kabupatenbangka-ten.

International Institute for Environment and Development (2002) 'Artisanal and smallscale mining', in Breaking new ground: Mining, minerals and Sustainable Development. IIED, pp. 314-334.

Available at: http://pubs.iied.org/G00905/.

Lumintang, F. M. (2013) 'Analisis pendapatan petani padi di Desa Teep Kecamatan Langowan Timur', Jurnal EMBA, 1(3), pp. 991-998. Available at:

https://ejournal.unsrat.ac.id/index.php/emba/a rticle/view/2304.

Marfirani, R. and Adiatma, I. (2012) 'Pergeseran mata pencaharian nelayan tangkap menjadi nelayan apung di Desa Batu Belubang', in Prosiding Seminar Nasional Pengelolaan Sumberdaya Alam dan Lingkungan, pp. 105114. Available at:

http://eprints.undip.ac.id/37618/1/014-

IRA_ADIATMA.pdf.

Nurtjahya, E., Agustina, F. and Putri, W. A. E. (2008) 'Neraca ekologi penambangan timah di Pulau Bangka studi kasus pengalihan fungsi lahan di ekosistem darat', Journal of Biological Researches, 14(1), pp. 29-38. doi: 10.23869/bphjbr.14.1.20085.

Pudjiastuti, T. N. (2005) 'The pressure of migrant illegal miners on the dynamical of local community: On 1998 Pongkor gold mining

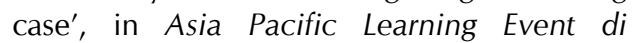
Filipina, pp. 1-15. Available at: https://www.researchgate.net/publication/237 626413 The Pressure of Migrant Illegal Mi ners_on_the_Dynamic_of_Local_Community _on_1998_Pongkor_Gold_Mining_Case.

Pudjiastuti, T. N. (2010) 'Dampak kegiatan penambangan emas terhadap sosial budaya dan ekonomi masyarakat di Bombana', in Zulkarnain, I. (ed.) Strategi pengembangan wilayah pertambangan rakyat di Kabupaten Bombana, Sulawesi Tenggara. LIPI Press, pp. 89-138.

Subiman, N. L. and Resosudarmo, B. P. (2010) 'Tambang untuk kesejahteraan masyarakat: Konflik dan usaha penyelesaiannya', in Azis, I. J., Napitupulu, L. M., Patunru, A. A., and Resosudarmo, B. P. (eds) Pembangunan BerkelanjutanPeran dan Kontribusi Emil Salim. PT Gramedia, pp. 426-449. 
Sujitno, S. (2007) Sejarah penambangan timah di Indonesia abad 18-abad 20. Cet. 2. Cempaka Publishing.

Sukirno, S. (2006) Ekonomi pembangunan: Proses, masalah dan kebijakan. Kencana Prenada Media Group.

Zulkarnain, I. (ed.) (2010) Strategi pengembangan wilayah pertambangan rakyat di Kabupaten Bombana. LIPI Press.

Zulkarnain, I., Erman, E., Pudjiastuti, T. N. and Mulyaningsih, Y. (2005) Konflik di kawasan pertambangan timah Bangka Belitung: Persoalan dan alternatif solusi. Jakarta: LIPI Press. Available at:

https://www.academia.edu/998455/Konflik_di kawasan pertambangan timah Bangka Beli tung_persoalan_dan_alternatif_solusi.

Zulkarnain, I., Pudjiastuti, T. N., Sumardani A., E. T. and Sari, B. R. (2007) Peran dan dinamika pertambangan rakyat di Indonesia. Jakarta: LIPI Press. Available at:

https://www.academia.edu/2073231/Dinamik a dan_Peran_Pertambangan_Rakyat_di_Indo nesia? auto $=\overline{\text { download. }}$. 
